\title{
EVALUATION OF THE QUALITY OF PRIMARY EDUCATION BY TESTING 5 FROM THE TEACHER'S PERSPECTIVE
}

\author{
[HODNOTENIE KVALITY PRIMARNEHO VZDELAVANIA \\ TESTOVANIM 5 Z POHLADU UCITELOV]
}

\author{
Monika Brozmanova - Lucia Kocisova
}

doi: 10.18355/PG.2021.10.1.1

\begin{abstract}
Quality requirements in all areas of education and in all types of schools are one of the basic attributes on which the future of nations, states and humanity depends. The quality of education as a service of a publicly funded society is therefore subject to monitoring by government institutions. Evaluating the quality of a school means finding out data on pre-agreed aspects of school life, the processes that take place in it. In 2015, an innovated state educational program was introduced in primary education. It brought changes especially in the educational standards of individual subjects, where is the attention to performance standards. The content of the curriculum does not become the goal of education, but a means to achieve the goal, which is a competent student. National testing also tries to bring this change in the understanding of content closer to the creation of test tasks. Students tests results cannot be the only and most important measure of a school's quality. Students, parents and teachers need to focus on non-cognitive processes at school. The introduction of testing of 5th grade students was not accepted by teachers with an understanding of effort to increase the quality of education. The aim of the paper is to compare the opinions of teachers from 2017 with the opinions of teachers in 2020 and to find out whether there has been a change in the acceptance of testing of 5th grade students as a tool for measuring the quality of education after primary education.
\end{abstract}

\section{Key words}

school quality, educational process, testing, comparison of teachers' opinions, test tasks, evaluation criteria

\begin{abstract}
Anotácia
Požiadavky na kvalitu vo všetkých oblastiach vzdelávania a na všetkých druhoch škôl sú jedným zo základných atribútov, od ktorých závisí budúcnost' života národov, štátov a l'udstva. Kvalita vzdelávania ako služby spoločnosti financovanej z verejných zdrojov preto podlieha monitorovaniu vládnych inštitúcií. Hodnotenie kvality školy znamená zist'ovanie údajov o vopred dohodnutých aspektoch školského života, procesoch, ktoré v ňom prebiehajú. V roku 2015 bol v základnom školstve zavedený inovovaný štátny vzdelávací program. Priniesol zmeny najmä vo vzdelávacích štandardoch jednotlivých predmetov, kde sa pozornost' venovala výkonovým štandardom. Obsah učiva sa nestáva ciel'om vzdelávania, ale prostriedkom na dosiahnutie ciel'a, ktorým je kompetentný žiak. Národné testovanie sa tiež
\end{abstract}


snaží túto zmenu $\mathrm{v}$ chápaní obsahu približit' $\mathrm{k}$ tvorbe testovacích úloh. Výsledky testov žiakov nemôžu byt' jediným a najdôležitejším meradlom kvality školy. Žiaci, rodičia a učitelia sa musia v škole zamerat' na kognitívne procesy. Zavedenie testovania žiakov 5. ročníka nebolo učitel'mi akceptované a pochopené ako snaha o zvýšenie kvality vzdelávania. Ciel’om príspevku je porovnat' názory učitel'ov z roku 2017 s názormi učitel’ov v roku 2020 a zistit', či došlo k zmene v akceptácii testovania žiakov 5. ročníka ako nástroja na meranie kvality vzdelávania po ukončení primárneho vzdelávania.

\section{Kl'účové slová}

kvalita školy, vzdelávací proces, testovanie, porovnanie názorov učitel'ov, testovacie úlohy, hodnotiace kritériá

\section{1 Úvod}

V posledných rokoch sa častejšie vo vzt’ahu so vzdelávaním ohýba slovo kvalita. Vo svete existuje množstvo systémov manažérstva kvality, ale takmer všetky $\mathrm{v}$ podstate vychádzajú $\mathrm{z}$ filozofie manažérstva TQM (komplexné manažérstvo kvality), ktorá formuje zákazníkom riadený a učiaci sa podnik k tomu, aby dosiahol úplnú spokojnost' zákazníkov, a to vd’aka neustálemu zlepšovaniu podnikových procesov (Turek, 2007). Uvedená definícia sa týka viac priemyselného podniku ako školy samotnej, avšak v posledných rokoch sme svedkami zavádzania systému manažérstva kvality aj do všetkých typov škôl. Spoločnost' preferuje výkon a vonkajšie prejavy úspechu meraného zviditel'nením sa jednotlivca, často bez ohl'adu na spôsob, ako sa to deje. V postmodernom chápaní sa poukazuje práve na ten problém znalostnej spoločnosti, kde „to, čo sa ešte tvrdošijne nazýva vzdelanie, sa v súčasnosti neriadi možnost’ami a hranicami indivídua ani nemennými zdrojmi určitej kultúrnej tradície. Externé faktory - trh, zamestnanost', kvalita lokality a technologický rozvoj - sú teraz štandardy, ktorým má "vzdelanec" vyhoviet" (Liessmann, 2008, s. 51).

Odborná verejnost' polemizuje o potrebe identifikovat', aká je dobrá škola, teda škola kvalitná. V školstve sa pojem kvalita vzt'ahuje na niekol'ko prvkov, najmä na: vzdelávací systém, školu ako inštitúciu, vyučovací proces, učenie sa žiakov. Pri kvalite vzdelávacieho systému štátu ide o jeho filozofiu, ciele, obsah výchovy a vzdelávania, štruktúru školského systému, princípy riadenia, ale aj financovania školstva, tiež o flexibilitu a otvorenost' vzdelávacieho systému. Ked’že populačná krivka na Slovensku klesá, školy sa snažia získat' čo najvyšší počet žiakov a vysoká kvalita školy sa stáva podmienkou prežitia (existencie školy). Každá škola by mala mat' vypracovaný systém manažérstva kvality, ktorý by sa vzt’ahoval na všetky procesy, ktoré v nej prebiehajú a zahíňal všetkých zamestnancov školy. Najdôležitejším procesom prebiehajúcim $\mathrm{v}$ škole je práve vyučovací proces, preto jeho kvalita je rozhodujúcim prvkom aj pre celkovú kvalitu školy. V jednotlivých vyučovacích predmetoch výrazne ovplyvňuje kvalitu vyučovacieho procesu práve učitel'. (Bakx, Koopmanb, Kruijf, den Brok, 2015) vypracovali štúdiu o vnímaní kvality učitel’ov žiakmi základnej školy, v ktorej výskumne potvrdili, že učitelia určujú z vel'kej časti kvalitu 
vzdelávania. Učitel', prípadne skupina učitel'ov, $\mathrm{v}$ podstate zastupuje manažérstvo kvality $\mathrm{v}$ školách a vyvrcholením ich snahy je učenie sa žiakov a ich výsledky (Turek, 2007). Dobrí učitelia môžu pozitívne ovplyvnit' výsledky vzdelávania žiakov (McKinsey, 2007).

$\mathrm{Na}$ rozdiel od prístupu $\mathrm{k}$ meraniu kvality $\mathrm{v}$ šest'desiatych rokoch minulého storočia, ked' sa kvalita vzdelávania zameriavala vyslovene na množstvo naučeného a kvalitu pomôcok a metód, $v$ súčasnosti sa kvalita vzdelávania meria schopnost’ami žiaka použit' nadobudnuté vedomosti $\mathrm{v}$ d'alšom vzdelávaní, respektíve v bežnom živote (Juščáková a kolektív, 2013). Po roku 1989 sa spustila u nás i d’alších stredoeurópskych krajinách reforma vo vzdelávaní. $\mathrm{V}$ týchto rokoch boli vzdelávacie systémy nás i našich susedných krajín: Pol'ska, Mad'arska a Českej republiky založené na socialistickom modeli a čelili od roku 1990 podobnej politickej i hospodárskej situácii. Herbst, Wojciuk (2013) vypracovali komparatívnu analýzu štyroch vzdelávacích systémov, ktoré zdiel'ali mnoho podobných charakteristík, ale zvolili si odlišné vývojové cesty vo vzdelávacej politike, zaviedli odlišné inštitucionálne usporiadanie. Na základe komparatívnej štúdie sa ukazuje, že to mohlo mat' zásadný vplyv na výsledky vzdelávania.

Rýdl (2002) upozorn̆uje, že s pojmom kvalita vzdelávania súvisí značný subjektivizmus, pretože pojem je definovaný často nemeratel'nými a neuchopitel'nými fenoménmi - z hl'adiska štandardných kvantitatívnych metodologických postupov, čo výrazne deformuje poznanie skutočnosti. Průcha, Walterová a Mareš (2009, s. 137) vymedzujú kvalitu školy ako „,̌iaducu či optimálnu úroveň jej fungovania a jej produktov”. Spilková (2005) vymedzuje tri oblasti, ktoré by mal zahŕňat koncept kvalitnej školy:

1. vstupy a podmienky školy (materiálne, personálne zabezpečenie),

2. proces vzdelávania a fungovania školy (spôsob riadenia, klíma školy kvalita učebných procesov),

3. výsledky vzdelávania, vrátane dlhodobejších efektov.

Všetky tieto oblasti by mali byt' $\mathrm{v}$ hodnotení kvality školy vyvážené, ak je ktorákol'vek $\mathrm{z}$ nich prevažujúca, je pravdepodobné, že to bude mat' $\mathrm{v}$ budúcnosti negatívne dôsledky. Práve prevažujúci akcent na hodnotenie vzdelávacích výsledkov žiakov prostredníctvom testovania, ako jedného $\mathrm{z}$ najdôležitejších ukazovatel’ov kvality vzdelávania $v$ školách, sa stal dôvodom nespokojnosti pedagogickej verejnosti. V školách v Európe, ale aj v Amerike, sú testy typickým nástrojom merania vedomostí žiakov. Vo všeobecnosti však platí, že vedomosti, ktoré žiaci preukážu v testoch, nevypovedajú celkom o tom, ako žiaci učivo zvládli a či mu aj rozumejú.

Výsledkom medzinárodných testovaní (PISA, TIMSS), ale i testovaní na národnej úrovni (Testovanie 5, Testovanie 9, Maturita) je prikladaný vel'ký význam v externom hodnotení kvality vzdelávania v školách na Slovensku a vo vzt’ahu $\mathrm{k}$ tvorbe vzdelávacej politiky. Od roku 2015 realizuje NÚCEM formou celoplošného národného testovania aj meranie vzdelávacích výsledkov žiakov 5. ročníka všetkých základných škôl na Slovensku. Pri zavedení Testovania 5 (d'alej T5) sa zdvihla vlna nespokojnosti a kritiky zo strany pedagogickej verejnosti, najmä učitel’ov primárneho vzdelávania. Napriek nesúhlasnému názoru učitel’ov bolo testovanie spustené a stalo sa jedným zo základných ukazovatel’ov merania vzdelávacích výsledkov žiakov 
po ukončení primárneho vzdelávania. Pre Testovanie 5 sa využívajú NR-testy relatívneho výkonu (rozlišujúce, porovnávacie). Rozlišujú žiakov podla ich výkonu v teste, čiže dávajú možnost' žiakov vzájomne porovnat'. NÚCEM v prvých fázach testovania vytváral grafy, ktoré zobrazovali percentuálnu úspešnost' žiakov v testovaní podl'a krajov. Tieto grafy a z nich vychádzajúce rebríčky škôl, realizované externými spôsobmi hodnotenia, výrazne naštrbili vnímanie širokej verejnosti o pravom chápaní kvality jednotlivých škôl. Na výsledky celoplošných testovaní nemožno pozerat' iba cez percentuálne výsledky žiakov v teste. Do hodnotenia kvality školy vstupujú d'alšie determinanty, o ktorých sa $\mathrm{v}$ prvých hodnotiacich správach NÚCEMU zmieňovalo menej. Na Slovensku sa postupne udomácn̆uje pojem autoevalvácia školy, ktorá je založená na vlastných kritériách hodnotenia školy. Autoevalvácia je motiváciou pre d'alší rozvoj školy a zlepšovanie všetkých procesov súvisiacich s edukáciou žiakov. Naznačuje škole d’alšiu perspektívu a predurčuje budúcnost' školy. Umožňuje reguláciu školy a jej školského vzdelávacieho programu zvnútra. „Nerobí sa s ciel'om kontrolovat', ale s ciel'om zlepšovat"' (Babiaková, 2011, s. 7).

V súčasnosti je v školách hlavným ciel'om humanistický prístup k edukácii, orientácia výučby na rozvoj osobnosti každého žiaka. V základných školách, v ktorých prevažný počet tvoria žiaci zo sociálne znevýhodneného prostredia, by teda práca $\mathrm{s}$ ich špecifikami vo vzdelávaní mala byt' i najzákladnejším meradlom kvality vzdelávania. Celoplošné testovanie však robí z individualít štatistiku percentuálnej úspešnosti, čo je v nesúlade s myšlienkou spustenia procesu inklúzie, ku ktorej sa aktuálne slovenské školstvo hlási. Kolektív pracovníkov z iniciatívy To dá rozum (2020) upozorňuje na to, že obzvlášt' v primárnom vzdelávaní je potrebné kvalitu merat' najmä cez kvalitný proces výučby, ktorý sa realizuje v pozitívnej psychosociálnej klíme a výsledkom je spokojnost' žiaka s dosiahnutými vlastnými výsledkami. Učitelia realizujú výučbu v súlade $\mathrm{s}$ platným inovovaným Štátnym vzdelávacím programom pre primárne vzdelávanie (2015), a teda je zaručené, že sú napíňané vzdelávacie štandardy i kompetenčný profil absolventa primárneho vzdelávania. Ide najmä o kvalitu výberu metód, foriem výučby a hl'adanie spôsobov, ako s individualitou každého žiaka pracovat'. V tomto je kl'účovou osobou odborne a osobnostne pripravený učitel'. Ak výsledky v štandardizovaných meraniach nad'alej zostanú jedným z hlavných kritérií hodnotenia kvality školy, potom inkluzívny model nemusí nájst' podporu u učitel'ov, ba práve naopak..

Na svojej internetovej stránke NÚCEM uvádza, že ciel'om Testovania 5 je získat' objektívne informácie o výkone žiakov pri vstupe na 2 . stupeň ZŠ, overit' úroveň ich vedomostí a zručností, schopností aplikovat' poznatky v praktických úlohách a schopností logicky mysliet'. Ďalším ciel'om je poskytnút' školám, decíznej sfére a širokej odbornej verejnosti spätnú väzbu a komplexnejší obraz o vedomostiach a zručnostiach žiakov z testovaných predmetov, ktorá napomôže pri skvalitňovaní vyučovania. Reforma školstva V našej krajine po roku 1989 priniesla hlavne zmeny v oblasti ciel'ov edukácie, a to smerom od vedomostí ku kompetenciám. Podstatná zmena nastala i v chápaní obsahu učiva, nie ako ciel'a, ale prostriedku pre dosahovanie ciel’ov. Uvedeným požiadavkám sa prispôsobujú i vzdelávacie 
štandardy jednotlivých predmetov $\mathrm{v}$ inovovanom Štátnom vzdelávacom programe (2015) a aj koncepcia testovania. Po štyroch rokoch by mali tieto požiadavky reflektovat' aj učitelia a postupne prijímat' testovanie ako druh istej pedagogickej kontroly.

Výskumný problém: Zmenili sa názory učitel'ov zist'ované v roku 2017 na testovanie piatakov ako nástroja na hodnotenie vzdelávacích výsledkov po ukončení primárneho vzdelávania progresívnym smerom? Reflektujú učitelia po štyroch rokoch zmeny v spracovaní výsledkov T5 externou organizáciou NÚCEM a využívaní výsledkov $\mathrm{z}$ testovania smerom $\mathrm{k}$ zvyšovaniu kvality vyučovacieho procesu?

\section{Výsledky komparácie názorov učitel’ov na T5 v rokoch 2017 a 2020}

Výskumnú vzorku tvorili učitelia 1. a 2. stupňa (vyučujúci materinský jazyk a matematiku) základných škôl na Slovensku. Vzorka pozostávala $\mathrm{z}$ dvoch skupín, ktoré boli odlišné v čase zberu dát. Prvú skupinu tvorili učitelia, ktorí sa výskumu zúčastnili v marci v roku $2017(\mathrm{~N}=786)$ a druhú skupinu tvorili učitelia, ktorí sa zúčastnili výskumu v marci v roku $2020(\mathrm{~N}=940)$. Použitý bol dotazník vlastnej konštrukcie distribuovaný elektronicky. Dotazník obsahoval 15 otázok, ktoré zist’ovali: sociodemografické ukazovatele, názory učitel'ov na napínanie ciel'ov T5, na organizáciu a priebeh testovania, d'alej názory učitel’ov na vplyv testovania na edukačný proces, na hodnotenie učitel'ov vedením školy i na vzt'ahy v učitel'skom kolektíve. Získané dáta boli spracované v programe Excel a SPSS 22.0. Pod spracovaním výsledkov jednotlivých okruhov otázok je príslušná tabul'ka s výsledkami odpovedí.

\section{Názory učitel'ov na splnenie ciel’a testovania piatakov}

Takmer polovica učitel’ov (2017 - 49,5\%; 2020 - 49,4 \%) si myslí, že T5 čiastočne poskytuje spätnú väzbu o určitom výkone a tretina učitel’ov (2017 $34,5 \% ; 2020$ - 30,6 \%) uviedla, že T5 poskytuje výsledky len o spôsobilosti písat' test. Názor, že T5 spíňa vytýčené ciele je u učitel'ov vel'mi nízko zastúpený $(2017-2,9 \% ; 2020-4,8 \%)$ a názor, že T5 vôbec nespíña vytýčené ciele je približne u 1/8 učitel'ov (2017 - 12,5\%; 2020 - 14,4\%). Medzi odpoved'ami učitel'ov v rokoch 2017 a 2020 nie je štatisticky významný rozdiel $\left(\chi^{2}=7,113, d f=4, p=0,13\right)$.

Tabul'ka 1. Komparácia splnenia ciel’a testovania piatakov

\begin{tabular}{|l|l|l|l|l|}
\hline \multirow{2}{*}{} & 2017 & 2020 \\
\cline { 2 - 5 } & $\mathrm{N}$ & $\%$ & $\mathrm{~N}$ & $\%$ \\
\hline áno, T5 splňa vytýčené ciele & 23 & $2,9 \%$ & 45 & $4,8 \%$ \\
\hline áno, čiastočne, poskytuje spätnú väzbu o určitom výkone & 389 & $49,5 \%$ & 464 & $49,4 \%$ \\
\hline skôr nie, poskytuje výsledky len o spôsobilosti písat' test & 271 & $34,5 \%$ & 288 & $30,6 \%$ \\
\hline nie, T5 vôbec nesplńa vytýčené ciele & 98 & $12,5 \%$ & 135 & $14,4 \%$ \\
\hline neodpovedalo & 5 & $0,6 \%$ & 8 & $0,9 \%$ \\
\hline spolu & 786 & $100 \%$ & 940 & $100 \%$ \\
\hline
\end{tabular}

Názory učitel'ov na súlad úloh $\mathrm{v}$ testoch $\mathbf{T} 5$ so vzdelávacím štandardom Polovica učitelov v roku 2017 (56,1\%) si myslí, že medzi úlohami v testoch T5 a vzdelávacím štandardom je väčšinou súhlas, čo uviedla len 1/5 učitel'ov 
$(21,3 \%)$ v roku 2020. Naopak, skoro $2 / 3$ učitel'ov $(61,4 \%)$ v roku 2020 uviedlo, že tam súlad väčšinou nie je, a tak odpovedala približne $1 / 3$ učitel'ov $(37,3 \%)$ v roku 2017. Súlad medzi testom a vzdelávacím štandardom je vždy podl'a $1,7 \%$ učitel'ov v roku 2017 a podl'a $7,4 \%$ učitel'ov v roku 2020 . Súlad vôbec nevníma 1,9 \% učitel'ov v roku 2017 a 3,3 \% učitel'ov v roku 2020. Učitelia sa vo svojich názoroch líšia $\left(\chi^{2}=232,932, d f=4, p=0,000\right.$, Cramer $V=0,184)$. Praktická významnost' je stredná.

\section{Tabul'ka 2. Komparácia súladu úloh v testoch T5 so vzdelávacím} štandardom

\begin{tabular}{|l|l|l|l|l|}
\hline \multirow{2}{*}{} & 2017 & 2020 & \\
\cline { 2 - 5 } & $\mathrm{N}$ & $\%$ & $\mathrm{~N}$ & $\%$ \\
\hline áno, vždy & 13 & $1,7 \%$ & 70 & $7,4 \%$ \\
\hline väčšinou áno & 441 & $56,1 \%$ & 200 & $21,3 \%$ \\
\hline väčsinou nie & 293 & $37,3 \%$ & 577 & $61,4 \%$ \\
\hline vôbec nie & 24 & $3,1 \%$ & 62 & $6,6 \%$ \\
\hline neodpovedalo & 15 & $1,9 \%$ & 31 & $3,3 \%$ \\
\hline spolu & 786 & $100 \%$ & 940 & $100 \%$ \\
\hline
\end{tabular}

\section{Názory učitel'ov na mieru vplyvu zavedenia $T 5$ na edukačný proces $v$ testovaných predmetoch}

Skúšanie formou testovania $(2017$ - 9,7 \%; 2020 - 13,6 \%) a vplyv testovania hlavne v mesiacoch pred termínom testovania $(2017-46,1 \%$; $2020-53,5$ \%) je vo vyššej miere v odpovediach učitel’ov v roku 2020 ako učitel'ov v roku 2017. Naproti tomu, občasné zaradenie vybraných testových úloh do vyučovania $(2017-26,2 \% ; 2020-20,5 \%)$ a priebeh výučby rovnako ako pred zavedením T5 $(2017$ - $17 \% ; 2020$ - 11,4 \%) boli vo vyššej miere prítomné u učitel'ov v roku 2020. Rozdiely medzi názormi učitel’ov v rokoch 2017 a 2020 sú štatisticky významné $\left(\chi^{2}=26,214, d f=4, p=0,000\right.$, Cramer $V=0,055)$. Praktická významnost' je nízka.

Tabul'ka 3. Komparácia vplyvu zavedenia T5 na výučbu a hodnotenie

\begin{tabular}{|l|l|l|l|l|}
\hline & 2017 & 2020 \\
\cline { 2 - 5 } & $\mathrm{N}$ & $\%$ & $\mathrm{~N}$ & $\%$ \\
\hline áno, výrazne, začali sme skúšat hlavne testovaním & 76 & $9,7 \%$ & 128 & $13,6 \%$ \\
\hline $\begin{array}{l}\text { čiastočneáno, hlavne na konci školského roka v 4. roč. a } \\
\text { v mesiacoch pred termínom testovania v 5. roč. }\end{array}$ & 362 & $46,1 \%$ & 503 & $53,5 \%$ \\
\hline skôr nie, občas zaradime do výučby testové úlohy & 206 & $26,2 \%$ & 193 & $20,5 \%$ \\
\hline nie, výučba prebieha rovnako ako pred zavedením T5 & 134 & $17,0 \%$ & 107 & $11,4 \%$ \\
\hline neodpovedalo & 8 & $1 \%$ & 9 & $1 \%$ \\
\hline spolu & 786 & $100 \%$ & 940 & $100 \%$ \\
\hline
\end{tabular}

\section{Konkrétne aktivity príprav v škole na T5}

Krúžok na prípravu na testovanie je vo vyššej miere zastúpený v odpovediach učitel'ov v roku $2020(10,1 \%)$ ako učitel'ov v roku 2017 (5,2 \%). Zvýšenie počtu hodín SJL a MAT využitím disponibilných hodín v ŠkVP bolo približne u $1 / 5$ učitelov $(2017-18,4 \% ; 2020-18,3 \%)$, ako aj realizovanie doučovania žiakov pred prípravou na T5 (2017 - 19\%; 2020 22,9 \%), či zakúpenie publikácií s testami na prípravu na T5 (2017-20,6\%; $2020-20 \%)$. V odpovediach učitel'ov v rokoch 2017 a 2020 existuje 
štatisticky významný rozdiel v príprave na T5 konkrétnymi aktivitami $\left(\chi^{2}=\right.$ 24,82, $d f=5, p=0,000$, Cramer $V=0,055)$. Praktická významnost' je nízka.

Tabul'ka 4. Komparácia konkrétnych aktivít príprav v škole na T5

\begin{tabular}{|l|l|l|l|l|}
\hline & 2017 & 2020 \\
\cline { 2 - 5 } & $\mathrm{N}$ & $\%$ & $\mathrm{~N}$ & $\%$ \\
\hline áno, založili sme krúžok na prípravu na testovanie & 41 & $5,2 \%$ & 95 & $10,1 \%$ \\
\hline $\begin{array}{l}\text { zvýšili sme počet hodín SJL a MAT využitím } \\
\text { disponibilných hodín v ŠkVP }\end{array}$ & 145 & $18,4 \%$ & 172 & $18,3 \%$ \\
\hline realizujeme doučovania žiakov pred prípravou na T5 & 149 & $19 \%$ & 215 & $22,9 \%$ \\
\hline $\begin{array}{l}\text { zakúpili sme (rodičia finančne uhradili) publikácie s } \\
\text { testami na prípravu na T5 }\end{array}$ & 162 & $20,6 \%$ & 188 & $20 \%$ \\
\hline iné & 268 & $34,1 \%$ & 252 & $26,8 \%$ \\
\hline neodpovedalo & 21 & $2,7 \%$ & 18 & $1,9 \%$ \\
\hline spolu & 786 & $100 \%$ & 940 & $100 \%$ \\
\hline
\end{tabular}

\section{Názory učitel'ov na prípravu vlastných testov}

Viac ako polovica učitel'ov (2017 - 55,2 \%; 2020 - 54,9 \%) uviedla, že si testy na bežné hodnotenie pripravujú samostatne podl'a vlastného úsudku a približne tretina učitel'ov $(2017-31,3 \% ; 2020-32,6 \%)$ si väčšinou stiahne test z Virtuálnej knižnice či internetových stránok. Bloomovu taxonómiu pri tvorbe alebo výbere úloh používa vel'mi málo učitel'ov (2017 $8,9 \% ; 2020-7,2 \%)$, ako aj overené testy od kolegov $(2017-3,7 \% ; 2020$ $4,5 \%)$. Názory učitel'ov v prípravách testov na bežné hodnotenie žiakov v rokoch 2017 a 2020 sa štatisticky nelíšia $\left(\chi^{2}=2,354, d f=4, p=0,671\right)$.

Tabul'ka 5. Komparácia príprav testov na bežné hodnotenie žiakov

\begin{tabular}{|c|c|c|c|c|}
\hline & \multicolumn{2}{|c|}{2017} & \multicolumn{2}{|c|}{2020} \\
\hline & $\mathrm{N}$ & $\%$ & $\mathrm{~N}$ & $\%$ \\
\hline $\begin{array}{l}\text { samostatne, podl'a vlastného úsudku o ovládaní učiva } \\
\text { žiakmi }\end{array}$ & 434 & $55,2 \%$ & 516 & $54,9 \%$ \\
\hline použivam Bloomovu taxonómiu pri tvorbe úloh & 70 & $8,9 \%$ & 68 & $7,2 \%$ \\
\hline $\begin{array}{l}\text { väčšinou si stiahnem test } \mathrm{z} \text { virtuálnej knižnice, } \\
\text { internetových stránok }\end{array}$ & 246 & $31,3 \%$ & 306 & $32,6 \%$ \\
\hline vždy použivam overené testy od kolegov & 29 & $3,7 \%$ & 42 & $4,5 \%$ \\
\hline neodpovedalo & 7 & $0,9 \%$ & 8 & $0,9 \%$ \\
\hline spolu & 786 & $100 \%$ & 940 & $100 \%$ \\
\hline
\end{tabular}

\section{Názory učitel'ov na problémy žiakov s T5}

Skoro 3/4 učitel'ov $(2017$ - 75,3 \%; 2020 - 76,2 \%) uviedla, že problémom žiakov v súvislosti s T5 je čítanie zadania úloh s porozumením a približne 1/3 učitel'ov uvádza aj problém množstva úloh a strán, ktoré žiakov demotivujú $(2017-32,3 \% ; 2020-34,4 \%)$, či problémy zvládnut' stres $(2017-36,3 \%$; 2020 - 34,9\%). Nedostatočný čas na vyriešenie testu vníma ako problém 1/10 učitel'ov (2017 - 9,7 \%; 2020 - 9,6 \%) a problémy u žiakov s testovaním nevníma len percento učitel'ov $(2017-1,4 \% ; 2020-1,5 \%)$. Učitelia v roku 2020 v menšej miere vnímajú problém, že žiaci nemajú skúsenosti s takýmto typom preverenia vedomostí ako učitelia v roku 2017 $(2017-27,1 \% ; 2020-21,7 \%)$ a tento rozdiel je štatisticky významný $\left(\chi^{2}=\right.$ $6,805, d f=1, p=0,009$, Cramer $V=0,063)$. Praktická významnost' je nízka. 
Tabul'ka 6. Komparácia problémov žiakov v súvislosti s T5

\begin{tabular}{|l|l|l|l|l|}
\hline & \multicolumn{2}{l|}{ Vl7 } & 2020 \\
\cline { 2 - 5 } & $\mathrm{N}$ & $\%$ & $\mathrm{~N}$ & $\%$ \\
\hline nemajú žiadny problém & 11 & $1,4 \%$ & 14 & $1,5 \%$ \\
\hline nedostatočný čas na vyriešenie testu & 76 & $9,7 \%$ & 90 & $9,6 \%$ \\
\hline s čítaním zadania úloh s porozumením & 592 & $75,3 \%$ & 716 & $76,2 \%$ \\
\hline s množstvom úloh a strán, ktoré žiakov demotivujú & 254 & $32,3 \%$ & 323 & $34,4 \%$ \\
\hline zvládnut' stres & 285 & $36,3 \%$ & 328 & $34,9 \%$ \\
\hline $\begin{array}{l}\text { s obavami, že sa ich výsledky odrazia v hodnotení na } 2 . \\
\text { stupni }\end{array}$ & 96 & $12,2 \%$ & 129 & $13,7 \%$ \\
\hline $\begin{array}{l}\text { nemajú skúsenosti s takýmto typom preverovania } \\
\text { vedomostí }\end{array}$ & 213 & $27,1 \%$ & 204 & $21,7 \%$ \\
\hline iné & 29 & $3,7 \%$ & 36 & $3,8 \%$ \\
\hline
\end{tabular}

\section{Názory učitel'ov na prežívanie T5 žiakmi}

Skoro polovica učitel'ov si myslí, že žiaci sú motivovaní a tešia sa, ale aj sú stresovaní kvôli zodpovednosti (2017 - 48,9 \%; 2020 - 49,5\%). Viac ako 1/4 učitel'ov (2017 - $27 \% ; 2020$ - 26,5\%) ale uvádza, že žiaci sú demotivovaní, ale nerobia si z T5 „t’ažkú hlavu“ a viac ako $1 / 6$ učitel'ov si myslí, že žiaci sú vel'mi stresovaní a demotivovaní (2017 - 16,7 \%; 2020 - 17,9 \%). Len nízke percento učitel'ov (2017 - 6,1\%; 2020 - 4,6 \%) si myslí, že žiaci sú motivovaní a chcú ukázat' čo vedia. Medzi názormi učitel'ov v rokoch 2017 a 2020 neexistuje štatisticky významný rozdiel $\left(\chi^{2}=2,445, \mathrm{df}=4, \mathrm{p}=0,655\right)$.

Tabul'ka 7. Komparácia názorov na prežívanie T5 žiakmi

\begin{tabular}{|l|l|l|l|l|}
\hline & 2017 & 2020 \\
\cline { 2 - 5 } & $\mathrm{N}$ & $\%$ & $\mathrm{~N}$ & $\%$ \\
\hline sú motivovaní, chcú ukázat' čo vedia, T5 sa neboja & 48 & $6,1 \%$ & 43 & $4,6 \%$ \\
\hline $\begin{array}{l}\text { sú motivovaní, tešia sa, ale sú aj stresovaní kvôli } \\
\text { zodpovednosti }\end{array}$ & 384 & $48,9 \%$ & 465 & $49,5 \%$ \\
\hline sú demotivovaní, ale nerobia si z T5 „t’ažkú hlavu“ & 212 & $27 \%$ & 249 & $26,5 \%$ \\
\hline sú vel'mi stresovaní a demotivovaní & 131 & $16,7 \%$ & 168 & $17,9 \%$ \\
\hline spolu & 786 & $100 \%$ & 940 & $100 \%$ \\
\hline
\end{tabular}

\section{Názory učitel'ov na čas na vypracovanie testu v T5}

Polovica učitel'ov v roku 2017 (50,6 \%) si myslí, že čas na vyriešenie úloh v testoch T5 je dostatočný a tento názor zdiel'a viac ako polovica učitel'ov v roku 2020 (57,6 \%). Názor, že čas skôr nie je dostatočný a stíhajú len najlepší žiaci prezentuje skoro polovica učitel'ov v roku 2017 (43,9 \%) a viac ako 1/3 učitel'ov v roku 2020 (38,6 \%). Čas na vyriešenie úloh v testoch T5 nie je dostatočný podl'a nízkeho množstva učitel'ov $(2017$ - 4,2 \%; 2020 $2,7 \%)$. Rozdiely v názoroch učitel'ov v rokoch 2017 a 2020 sú štatisticky významné $\left(\chi^{2}=9,723, d f=3, p=0,021\right.$, Cramer $\left.V=0,043\right)$. Praktická významnost' je nízka. 
Tabul'ka 8. Komparácia názoru na dostatočnost' času na vyriešenie úloh $\mathrm{v}$ testoch $\mathrm{T5}$

\begin{tabular}{|l|l|l|l|l|}
\hline \multirow{2}{*}{} & \multicolumn{3}{|l|}{2017} & 2020 \\
\cline { 2 - 5 } & $\mathrm{N}$ & $\%$ & $\mathrm{~N}$ & $\%$ \\
\hline určite áno, väčšine žiakov postačuje & 398 & $50,6 \%$ & 541 & $57,6 \%$ \\
\hline skôr nie, stíhajúlen najlepš́ žiaci & 345 & $43,9 \%$ & 363 & $38,6 \%$ \\
\hline rozhodnenie, ani najlepší žiaci nestíhajú & 33 & $4,2 \%$ & 25 & $2,7 \%$ \\
\hline neodpovedalo & 10 & $1,3 \%$ & 11 & $1,2 \%$ \\
\hline spolu & 786 & $100 \%$ & 940 & $100 \%$ \\
\hline
\end{tabular}

\section{Názory učitel'ov na termín testovania 75}

Porovnanie názorov učitel'ov v roku 2017 a 2020 na termín testovania vykazuje takmer úplnú zhodu. Polovica učitel'ov (2017 - 51,9\%; 2020 $51,9 \%$ ) uviedla, že testovanie T5 by malo byt' v júni 4 . ročníka a $1 / 3$ učitel'ov sa vyjadrila, že vôbec nesúhlasia s testovaním žiakov 5. ročníka (2017 - 31,3 \%; 2020 - 33,2 \%). Približne 1/10 učitel'ov uviedla (2017 $13 \% ; 2020-10 \%$ ), že súhlasia s termínom testovania a nízke percento učitel'ov $(2017-3,4 \% ; 2020-3,8 \%)$ by testovanie posunulo na september 5. ročníka. Názory učitel’ov v rokoch 2017 a 2020 sa štatisticky nelíšia $\mathrm{v}$ návrhoch na termín testovania T5 $\left(\chi^{2}=6,643, d f=4, p=0,156\right)$.

\section{Tabul'ka 9. Komparácia návrhu termínu testovania}

\begin{tabular}{|l|l|l|l|l|}
\hline & 2017 & 2020 \\
\cline { 2 - 5 } & $\mathrm{N}$ & $\%$ & $\mathrm{~N}$ & $\%$ \\
\hline súhlasím s termínom & 102 & $13 \%$ & 94 & $10 \%$ \\
\hline posunul(a) by som ho na september5. ročníka & 27 & $3,4 \%$ & 36 & $3,8 \%$ \\
\hline testovanie by malo byt' vúni 4. ročníka & 408 & $51,9 \%$ & 488 & $51,9 \%$ \\
\hline nesúhlasím vôbec s testovaním žiakov 5. ročníka & 246 & $31,3 \%$ & 312 & $33,2 \%$ \\
\hline neodpovedalo & 3 & $0,4 \%$ & 10 & $1,1 \%$ \\
\hline spolu & 786 & $100 \%$ & 940 & $100 \%$ \\
\hline
\end{tabular}

Názory učitel'ov na vplyv testovania na ich hodnotenie vedením školy

Skoro polovica učitel'ov $(2017-45,4 \% ; 2020$ - 44,5 \%) uviedla, že T5 skôr nemá vplyv na ich hodnotenie vedením školy, tretina učitel'ov (2017 $32,4 \% ; 2020$ - 34,5 \%) uviedla, že čiastočne má vplyv a šestina učitel’ov (2017 - 15,5\%; 2020 - 13,4 \%) uviedla, že T5 nemá vplyv na ich hodnotenie vedením školy. Menej ako desatina učitel’ov (2017 - 6,4\%; 2020 - 6,6\%) uviedla, že výsledky v T5 majú vel'ký vplyv na hodnotenie konkrétneho učitel'a 4. ročníka. Medzi názormi učitel’ov v rokoch 2017 a 2020 neexistuje štatisticky významný rozdiel $\left(\chi^{2}=6,015, d f=4, p=0,198\right)$. 
Tabul'ka 10. Komparácia vplyvu testovania na hodnotenie učitel'ov

\begin{tabular}{|l|l|l|l|l|}
\hline & 2017 & 2020 \\
\cline { 2 - 5 } & $\mathrm{N}$ & $\%$ & $\mathrm{~N}$ & $\%$ \\
\hline $\begin{array}{l}\text { áno, výsledky v T5 majú vel'ký vplyv na hodnotenie } \\
\text { konkrétneho učitel'a }\end{array}$ & 50 & $6,4 \%$ & 62 & $6,6 \%$ \\
\hline $\begin{array}{l}\text { čiastočneáno, ale v našej škole sa učitelia hodnotia aj } \\
\text { na základe iných kritérii }\end{array}$ & 255 & $32,4 \%$ & 324 & $34,5 \%$ \\
\hline $\begin{array}{l}\text { skôr nie, len sa výsledky vyhodnocujú na pedagogickej } \\
\text { rade a zasadnutiach MZ }\end{array}$ & 357 & $45,4 \%$ & 418 & $44,5 \%$ \\
\hline $\begin{array}{l}\text { nie, výsledky T5 majú pre naše vedenie len } \\
\text { informatívny charakter }\end{array}$ & 122 & $15,5 \%$ & 126 & $13,4 \%$ \\
\hline neodpovedalo & 2 & $0,3 \%$ & 10 & $1,1 \%$ \\
\hline spolu & 786 & $100 \%$ & 940 & $100 \%$ \\
\hline
\end{tabular}

\section{Názory učitel'ov vplyvu testovania na vzt'ahy v kolektíve}

Tri štvrtiny učitel'ov (2017 - 76,7 \%; 2020 - 73,3 \%) vníma vzt'ahy na pracovisku medzi učitel'mi 1. a 2. stupňa za dobré a testovanie ich neovplyvňuje. Približne desatina učitel'ov uviedla, že sa vzt'ahy zlepšili (2017 $-6,6 \% ; 2020-9,1 \%$ ) a desatina učitel'ov, že sa vzt'ahy zhoršili práve kvôli výsledkom v T5 (2017 - 9,5\%; 2020 - 11,9 \%). Nízke percento učitel'ov $(2017-5,9 \% ; 2020-3,6 \%)$ hodnotí vzt'ahy medzi 1. a 2. stupňom na ich škole ako trvale zlé. Učitelia sa líšia v hodnotení vzt'ahov na pracovisku medzi učitel'mi 1. a 2. stupňa $\left(\chi^{2}=12,373, d f=4, p=0,015\right.$, Cramer $V=$ $0,045)$. Praktická významnost’ je nízka.

Tabul'ka 11. Komparácia hodnotenia vzt'ahov na pracovisku medzi učitel'mi 1. a 2. stupňa

\begin{tabular}{|l|l|l|l|l|}
\hline \multirow{2}{*}{} & 2017 & 2020 \\
\cline { 2 - 5 } & $\mathrm{N}$ & $\%$ & $\mathrm{~N}$ & $\%$ \\
\hline máme dobré vzt’ahy, testovanie ich neovplyvnnuje & 603 & $76,7 \%$ & 689 & $73,3 \%$ \\
\hline vzt'ahy sa zlepšili, ide nám o spoločnú vec & 52 & $6,6 \%$ & 86 & $9,1 \%$ \\
\hline vzt'ahy sa zhoršili práve kvôli výsledkom v T5 & 75 & $9,5 \%$ & 112 & $11,9 \%$ \\
\hline vzt’ahy medzi 1. a 2. stupňom sú v našej škole trvale zlé & 46 & $5,9 \%$ & 34 & $3,6 \%$ \\
\hline neodpovedalo & 10 & $1,3 \%$ & 19 & $2 \%$ \\
\hline spolu & 786 & $100 \%$ & 940 & $100 \%$ \\
\hline
\end{tabular}

Názory učitel'ov na zmenu v kvalite výučby vd'aka zavedeniu T5

Skoro 2/3 učitel'ov (2017 - 61,5 \%; 2020 - 61,9 \%) vníma, že kvalita výučby vd'aka zavedeniu T5 ostane rovnaká a približne 1/3 učitel'ov (2017 - 30,7 \%; 2020 - 29,1 \%) uviedla, že kvalita sa zníži práve dôsledkom toho, že sa budú precvičovat' testové úlohy. Len vel'mi nízke percento učitel'ov $(2017-5,7 \%$; 2020 - 7,9 \%) uviedlo, že určite sa kvalita výučby zvýši. Učitelia sa $\mathrm{v}$ názoroch na zmenu $\mathrm{v}$ kvalite výučby vd'aka zavedenie T5 nelíšia $\left(\chi^{2}=\right.$ $6,511$, df $=3, p=0,089)$. 
Tabul'ka12. Komparácia názorov na zmenu v kvalite výučby zavedením

T5

\begin{tabular}{|l|l|l|l|l|}
\hline \multicolumn{2}{|l|}{} & 2017 & 2020 \\
\cline { 2 - 5 } \multicolumn{1}{c|}{} & $\mathrm{N}$ & $\%$ & $\mathrm{~N}$ & $\%$ \\
\hline určite áno, bude vyššia kvalita výučby & 45 & $5,7 \%$ & 74 & $7,9 \%$ \\
\hline $\begin{array}{l}\text { nie, zostane rovnaká, žiaci budú len vediet' lepšie písat' } \\
\text { testy }\end{array}$ & 483 & $61,5 \%$ & 582 & $61,9 \%$ \\
\hline $\begin{array}{l}\text { kvalita sa zníži, lebo namiesto rôznorodých metód } \\
\text { výučby sa budú precvičovat' testové úlohy }\end{array}$ & 241 & $30,7 \%$ & 274 & $29,1 \%$ \\
\hline neodpovedalo & 17 & $2,2 \%$ & 10 & $1,1 \%$ \\
\hline spolu & 786 & $100 \%$ & 940 & $100 \%$ \\
\hline
\end{tabular}

\section{Závery výskumu, diskusia k názorom učitel’ov}

Výsledky ukázali, že názory učitel’ov na Testovanie 5 sa počas štyroch rokov výrazne nezmenili. Názory učitel'ov na splnenie ciel'ov testovania ostali rovnaké (pozri tabul'ku 1) napriek tomu, že NÚCEM ciele modifikoval a od striktného vyhodnocovania vzdelávacích výsledkov postupne prechádza aj na poskytovanie spätnej väzby konkrétnym školám. Poskytovanie adresnej spätnej väzby školám pre autoevalvačné účely považuje NÚCEM za jeden z klúčových výstupov externých meraní. Tento fakt však učitelia $\mathrm{v}$ zmene názorov na ciele testovania nereflektovali. Na základe výsledkov odpovedí na otázku, či sledujú učitelia internetovú stránku NÚCEMu, sa zhodne v obidvoch rokoch učitelia v 50 percentách vyjadrili (2017 - 50,9 \%, 2020 $52,4 \%$ ), že stránku niekedy navštívia, najmä však pred a tesne po testovaní. Iba okolo $1 / 5$ učitel'ov (2017 - 22,1\% a 2020 - 24,5\%) stránku sleduje pravidelne. Súhrnné správy o výsledkoch testovania a analýzy testových úloh zverejňuje NÚCEM nie hned' po testovaní, ale neskôr, po ich spracovaní. Na základe výsledkov odpovedí učitel'ov sa ukázalo, že prevažná čast' učitel'ov tieto správy vôbec nečíta. Práve analýzy v správach sú pre skvalitňovanie vyučovacieho procesu vysoko prínosné tým, že obsahujú podrobnú analýzu výsledkov žiakov v jednotlivých úlohách v testoch.

Názory učitel’ov na otázku týkajúcu sa súladu úloh v teste so vzdelávacím štandardom testovaných predmetov sa stávajú priestorom pre diskusiu o tvorbe testu v T5 (pozri tabul'ku 2). Pre rešpektovanie požiadavky na validitu testu je potrebné zaradit' testové úlohy tak, aby účelne pokrývali a vystihovali učivo, ktoré je vo vzdelávacom štandarde predmetu. Brozmanová (2017) v analýze testových úloh v T5 v rokoch 2015 a 2016 uvádza, že pomer zastúpenia úloh podl’a jednotlivých tematických celkov má výrazný vplyv na celkovú úspešnost' žiakov $\mathrm{v}$ teste. Ide o požiadavku rešpektovat' pri zostavovaní úloh do testov i časovú dotáciu, ktorú majú jednotlivé vzdelávacie obsahy $\mathrm{v}$ testovaných predmetoch $\mathrm{v}$ primárnom vzdelávaní, a tiež dôsledne $\mathrm{v}$ úlohách rešpektovat' požiadavky uvedené vo výkonovom štandarde $\mathrm{k}$ danému vzdelávaciemu obsahu. $\mathrm{V}$ teste $\mathrm{z}$ materinského jazyka T5-2015 aj T5-2016 v testovanej oblasti jazyk a komunikácia bolo v tematickom okruhu morfológia až pät' úloh $\mathrm{z}$ desiatich $\mathrm{z}$ učiva o slovných druhoch. Žiaci sa začínajú so slovnými druhmi oboznamovat' až v 2. polroku 3. ročníka. Až v 2. polroku 4. ročníka získavajú vedomosti o gramatických javoch, ktoré boli obsahom testových úloh v T5-2015 i T5-2016. Priemerná 
úspešnost' žiakov v týchto úlohách bola: 44,1 \% v T5- 2015 a 52,3 \% v T52016. Z uvedeného vyplýva, že nízka úspešnost' práve v týchto úlohách, výrazne ovplyvňovala celkovú úspešnost' v teste (Brozmanová, 2017).

Ďalšou dominantnou oblast'ou v testoch T5 z materinského jazyka je oblast' úloh na čítanie s porozumením. „Rozvinutie čitatel'skej gramotnosti každého žiaka na potrebnú úroveň by malo byt' jedným zo základných ciel'ov vzdelávania. Učitel' by mal podporovat' každého jedného žiaka a učit' ho efektívnym stratégiám, ktoré sú vhodné a šité priamo na mieru pre konkrétneho jednotlivca, vychádzajúc z jeho osobnosti, učebného tempa a učebného štýlu. Celoživotné učenie sa nezaobíde bez aktívneho čítania spojeného so skutočným porozumením textu" (Hosova, 2019, s. 182). Oproti testom $\mathrm{z}$ matematiky je badatel'ný výrazný vplyv požiadaviek $\mathrm{Z}$ medzinárodných meraní čitatel'skej gramotnosti pre zostavovanie úloh do testov na národnej úrovni.

Požiadavky vo výkonovom štandarde $\mathrm{v}$ inovovanom štátnom vzdelávacom programe sú zamerané na rozvíjanie vyšších kognitívnych úrovní myslenia, na čo apelujú aj výsledky $\mathrm{v}$ testovaní. Pod nižšiu úspešnost' žiakov $\mathrm{v}$ testovaní sa totiž podpisujú práve úlohy na aplikáciu, analýzu a hodnotenie. Otázne však ostáva, do akej miery učitelia požiadavky na výkonový štandard vo vzt’ahu $\mathrm{k}$ jednotlivým žiakom napĺnajú. Do zist'ovania názorov prostredníctvom dotazníka sa aj v roku 2017 i 2020 zapojilo najvyššie percento učitel'ov práve z krajov východného Slovenska (Prešovský kraj: 2017 - 18,3 \%, rok 2020 18,15 \% a Košický kraj: 2017 - 14,1 \% a 2020 $15,6 \%$ ). V týchto krajoch je vysoký podiel žiakov zo SZP a učitelia pracujú so žiakmi, ktorí majú väčšie vzdelávacie problémy.

Učitelia v obidvoch rokoch takmer zhodne zvolili odpovede na otázku, s čím majú žiaci najväčší problém v Testovaní 5 (pozri tabul'ku 6). Uviedli, že množstvo úloh, počet strán $\mathrm{v}$ testoch i vyčlenený čas na vypracovanie testu $\mathrm{v}$ T5 pôsobí na žiakov stresujúco, pretože s vypracovaním 10-stranového testu sa v primárnom vzdelávaní nestretávajú vôbec. Ak áno, tak v prípade, že im je cielene predložený, teda učitelia využívajú pri príprave žiakov na T5 testy z predošlých rokov. V otvorených otázkach to učitelia i uviedli, že príprava sa realizuje aj využívaním testov z predošlých rokov. Dokonca, že tieto testy sa neraz využívajú i ako vstupné testy do 5. ročníka z testovaných predmetov. V komparácii názorov učitel’ov na vplyv zavedenia T5 na výučbu a hodnotenie testovaných predmetov sme zaznamenali práve zvýšeniu počtu odpovedí v roku 2020, že učitelia začali preverovat' vedomosti žiakov hlavne formou testovania, a to najmä na konci 4. ročníka a v mesiacoch tesne pred testovaním (pozri tabul'ku 3).

Od roku 2017 sa však nezmenil prístup učitel'ov k tvorbe vlastných testov na hodnotenie žiakov, čo je alarmujúce zistenie (pozri tabul'ku 5). V primárnom vzdelávaní nevyužívajú učitelia na hodnotenie žiakov prioritne testy, napriek tomu je potrebné si uvedomit', že testy slúžia na objektivizovanie hodnotenie učitel’a aj u žiakov v primárnom vzdelávaní. Anderson, Krathwohl (2001) uvádzajú taxonomické usporiadanie úloh od najnižšej kognitívnej úrovne po najvyššiu, ktorú reprezentuje aj Bloomova taxonómia. Zistili sme, že ju pri tvorbe vlastných testov pre žiakov využíva necelých $10 \%$ učitel'ov (v roku 2020 dokonca menej ako v roku 2017). Väčšina učitel'ov si svoju prácu pri 
tvorbe vlastného testu pre žiakov zjednodušuje stiahnutím testu z Virtuálnej knižnice. Trnka (2004) v tejto súvislosti uvádza, že kritériom pre reprezentatívnost' úloh zaradených do testu sú úlohy zamerané na vyššie úrovne učiva (porozumenie a použitie vedomostí), pretože správne vyriešenie týchto úloh predurčuje zvládnutie nižšej úrovne učiva (mechanické vedomosti, zapamätanie). V roku 2020 sa do dotazníka zapojilo vyššie percento učitel'ov s pedagogickou praxou do 10 rokov. Táto skutočnost' vedie aj k zamysleniu sa nad prípravou učitel'ov v smere realizácie kontrolných procesov vzdelávania. Bolo by prínosné už vo vysokoškolskom štúdiu pripravovat' učitel'ov tak, aby disponovali kompetenciami tvorit' úlohy do testov, a teda viac pracovat's uplatňovaním taxonómií kognitívnych cielov. Vo vztahu $\mathrm{k}$ vplyvu zavedenia testovania piatakov na vyučovací proces je potrebné citlivo vnímat', že $\mathrm{v}$ mesiacoch pred termínom testovania sa až $53,5 \%$ učitel'ov venuje preverovaniu vedomostí testami. Je to obdobie opakovania učiva, čo je $\mathrm{v}$ súlade $\mathrm{s}$ preverovaním aj formou testu, ale $\mathrm{z}$ hladiska obdobia adaptácie pri prechode na vyšší stupeň vzdelávania to na žiakov môže pôsobit' stresujúco. Výučba by sa nemala $\mathrm{v}$ ciel'ovej rovine zameriavat' na riešenie testových úloh za účelom zlepšenia percentuálnej úspešnosti v testoch, ale na samotné skvalitnenie procesu výučby tak, aby žiaci dosiahli vyššiu úspešnost' $v$ testoch. Vypracovávanie vzorových testov a testov z minulých rokov nemá pridanú hodnotu z hladiska rozvoja žiaka. Od času prvého celoplošného testovania piatakov sa začali vydávat' rôzne publikácie, ktoré poskytujú úlohy na prípravu žiakov na testovanie. Mnohé školy ich zakupujú pre svojich žiakov a cielene žiakov na testovanie pripravujú. Svedčí o tom i vyšší percentuálny výsledok odpovedí o založení krúžku, ktorý sa venuje príprave na testovanie (v roku 2020 oproti roku 2017). Dá sa teda konštatovat', že testovanie žiakov v rámci T5 zasiahlo aj do organizácie výučby, pretože učitelia $\mathrm{v}$ odpovediach $\mathrm{v}$ roku 2020 ešte vo vyššom percente ako v roku 2017 uvádzajú, že v školách realizujú i doučovanie žiakov s ciel'om pripravit' ich na testy (pozri tabul'ku 4).

Učitelia vyjadrili $\mathrm{v}$ obidvoch rokoch takmer úplnú zhodu v názore na termín testovania (pozri tabul'ku 9). Zhodujú sa, že ak T5 realizovat', tak na konci 4. ročníka primárneho vzdelávania. Ale zásadnejší je fakt, že tretina učitel’ov úplne odmietla testovanie T5. V otvorenej otázke o negatívach zavedenia T5 učitelia uviedli ako najpodstatnejšie: stres žiakov, učitel'ov i rodičov pred T5, neprimeranost' testu veku žiakov, nesúlad so vzdelávacím štandardom predmetov, náročné texty $\mathrm{v}$ teste $\mathrm{z}$ materinského jazyka, $\mathrm{z}$ ktorých úlohy vychádzajú, tiež nepreberanie učiva $\mathrm{v} 5$. ročníku na úkor prípravy na T5, neobjektívne porovnávanie škôl, ktoré je prezentované $\mathrm{v}$ médiách.

Za pozitívne zistenie $\mathrm{v}$ opätovnom dotazníku možno považovat', že na hodnotenie konkrétneho učitel'a vedením školy nemá zavedenie T5 negatívne dopady ani po štyroch rokoch. Z dotazníka vyplynulo, že riaditelia škôl využívajú na hodnotenie práce učitel'ov aj d’alšie nastavená kritériá hodnotenia (pozri tabul'ku 10). Čo sa týka vplyvu T5 na vzt’ahy v kolektíve medzi učitel'mi 1. a 2. stupňa, T5 nezasahuje významne do formovania vzt’ahov medzi učitel'mi. Úroveň ich vzájomných pracovných vzt’ahov hodnotili učitelia rovnako aj v roku 2017 aj v roku 2020, prevažne na dobrej úrovni a výsledky testovania ich neovplyvňujú (pozri tabul'ku 11). 
Opätovným zist'ovaním názorov učitel'ov na T5 po uplynutí štyroch školských rokov sa ukázalo, že prvotne vytvorený názor na testovanie piatakov si učitelia výrazne neformujú, a to ani zmenou nastavených ciel'ov NÚCEMu. Poskytovanie adresnej spätnej väzby školám by mohlo významnejšie ovplyvnit' názor učitel'ov na realizáciu testovania. V autoregulatívnom systéme školy by sa dáta získané kontrolou mali stat' kritériom na korekcie postupov. Brown, Bull, Pendleburry, (1997) uvádzajú, že zmyslom spätnej väzby je poskytnút' žiakovi pomoc, aby zlepšil to, čo robí. Túto pomoc mu môže poskytnút' len profesionálne a osobnostne kompetentný učitel'. V prípade výsledkov T5 je potrebná spätná väzba $\mathrm{z}$ NÚCEMu, a to spracovaním výsledkov žiakov konkrétnej školy tak, aby mohli učitelia pracovat' na korekcii chýb v testových úlohách.

Názory učitel’ov na otázky vplyvu T5 na zvyšovania kvality výučby sa ani po rokoch nezmenili. Takmer $2 / 3$ učitel'ov si myslí, že sa kvalita výučby zavedením testovania nezvýšila a ani nezvýši, iba sa žiaci naučia lepšie písat' testy (pozri tabul'ku 12). V medzinárodnom výskume vyučovania a vzdelávania TALIS 2013, ktorý sa realizoval aj na Slovensku, sa zistilo, že iba 10 percent slovenských učitel'ov realizovalo individuálny alebo skupinový výskum $\mathrm{v}$ oblasti svojho profesionálneho záujmu, t.j. v oblasti vzdelávania. Nedostatočná teoretická príprava a praktické skúsenosti našich učitel'ov s vedecko-výskumnou prácou v oblasti vzdelávania znižujú aj možnosti uplatnenia spätnej väzby výskumov vzdelávania realizovaných externými inštitúciami. Práve uvedená informácia evokuje k odporúčaniu, aby učitelia venovali zvýšenú pozornost' analýzam, ktoré na svojich stránkach uverejňuje NÚCEM a aplikovali zistenia $\mathrm{z}$ nich do zvyšovania kvality ich vlastného vyučovacieho procesu. $\mathrm{V}$ rámci výpovednej hodnoty Testovania 5 o kvalite vzdelávania $\mathrm{v}$ školách na Slovensku je však nutné zdôraznit', aby štát považoval výsledky len za výsledky vedomostí žiakov a doplńă ich aj d’alšími ukazovatel'mi kvality v konkrétnej škole.

\section{Bibliographic references}

ANDERSON, L. W. - KRATHWOHL, D. R. 2001. A Taxonomy for Learning, Teaching, and Assessing: A Revision of Bloom's Taxonomy of Educational Objectives. New York: Longman. ISBN 80-200-0524-2

BABIAKOVA, S. 2013. Autoevalvácia skoly a ucitela. Banska Bystrica: PF UMB. ISBN 978-80-557-0569-9

BABIAKOVA, S. A KOL. 2014. Progresivny ucitel. Autoevalvacia v teoriach a vyskumoch. Banska Bystrica: Belianum. ISBN 978-80-557-0738-9 BAKX, A. - KOOPMANB, M. - KRUIJF, J. - BROK, P. 2015. Primary school pupils' views of characteristics of good primary school teachers: an exploratory, open approach for investigating pupils' perceptions, Teachers and Teaching, vol. 21, n. 5, pp. 543-564

BROWN, G. - BULL, J. - PENDLEBURRY, M. 1997. Assesing Student Learning in Higher Education. London: Routledge.

BROZMANOVA, M. 2017. Analyza testovania vzdelavacich vysledkov ziakov primarneho stupna skoly $\mathrm{v}$ narodnom kontexte. Dizertacna praca. 34ee784b-2703-425f-b72a-a1501a91fb00 
EURYDICE. 2009. National Testing of Pupils in Europe: Objectives, Organisation and Use of Results, European Commission.

HERBST, M. - WOJCIUK, A. 2014. Common legacy, different paths: the transformation of educational systems in the Czech Republic, Slovakia, Hungary and Poland. Compare: A Journal of Comparative and International Education, vol. 47, n. 1, pp. 118-132

HOSOVA, D. 2019. Rozvijanie citatelskych zrucnosti pomocou vybranych strategii. In: Slavonic Pedagogical Studies Jornal, vol. 8, n. 1, pp. 176-184. ISSN 1339-8660

JUSCAKOVA A KOL. 2013. Indikatory kvality vzdelavania v hodnoteni skol. Bratislava: Nucem. ISBN 978-80-89638-16-1

KOLEKTIV AUTOROV. 2020. Odporucania pre skvalitnenie skolstva na Slovensku To da rozum. Available online:

https://todarozum.sk/admin/files/file_879_1587651772.pdf

LIESSMANN, K.P. 2008. Teorie nevzdelanosti. Omyly spolecnosti vedeni. Praha: Academia. ISBN 978-80-200-1677-5

MCKINSEY, 2007. How the world best performing school systems come out on top. London: Author.

NUCEM. 2015. Metodika tvorby testovych uloh. Available onlne: http://www.etest.sk/data/files/1917_metodika-tvorby-testovych-uloh-atestov-kubis-2015.pdf

PRUCHA, J. - WALTEROVA, E. - MARES, J. 1995. Pedagogicky slovnik. Praha: Portal. ISBN 80-7178-029-4

RYDL, K. 2002. K pojeti kvality ve skolstvi a jejimu hodnoceni. Epedagogikum, vol.2, n. 1, 104 p.

SPILKOVA, V. 2004. Soucasne promeny vzdelavani ucitelu. Brno: Paido.

STATPEDU. 2015. Statny vzdelavaci program. Bratislava: Statpedu, Available online:

https://www.statpedu.sk/files/articles/dokumenty/inovovany-statnyvzdelavaci-program/svp_pv_2015.pdf

TRNKA, M. 2004. Didakticky test - prostriedok rozvijajuceho hodnotenia vo vyucovani prvouky. B. Bystrica: PF UMB. ISBN 80-8033-004-5

TUREK, I. 2007. O kvalite vzdelavania. In: Manazment skoly, c. 4/2007, pp. 2-6 ISSN 1336-9849

TALIS. ZAKLADNE INFORMACIE O VYSLEDKOCH STUDIE OECD TALIS. 2013.2 Available online: http://www.nucem.sk/documents/27/medzinarodne_merania/talis/publikacie/i ne/TALIS_2013_-_prvotne_zistenia.pdf 
PaedDr. Monika Brozmanová, PhD.

Katedra elementárnej a predškolskej pedagogiky

UMB in Banska Bystrica,

Faculty of education

Ružová 13, 97411 Banská Bystrica,

Slovakia

monika.brozmanova@umb.sk

PhDr. et Mgr. Lucia Kočišová, PhD.

Centre of Social and Psychological Sciences SAS

Slovak Academy of Sciences

Šancová 56, 81105 Bratislava

Slovakia

luci.kocisova@gmail.com 